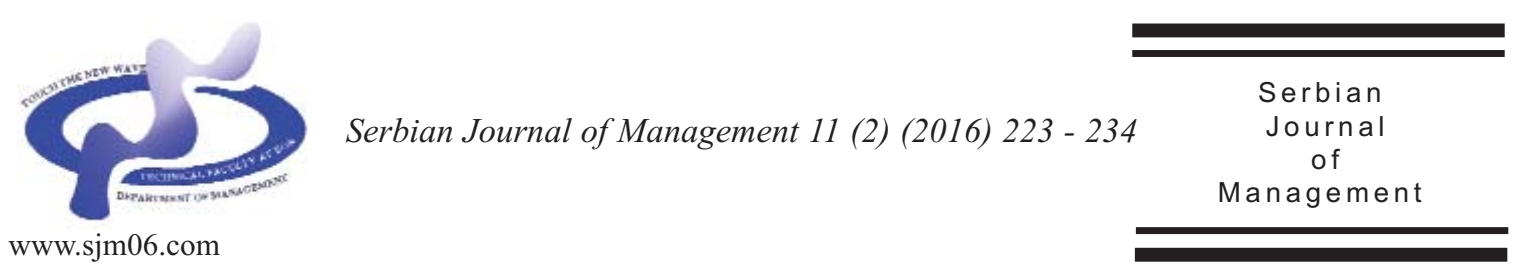

\title{
METHODOLOGICAL AND PRACTICAL ASPECTS OF THE HARMONIZATION OF INNOVATIVE PROCESSES IN RUSSIAN SMALL BUSINESS SECTOR
}

\author{
Yuri Anatolievich Doroshenko and Irina Vladimirovna Somina* \\ Belgorod state technological university named after V.G. Shukhov, \\ Kostyukov str., b.46., Belgorod, 308012, Russia
}

(Received 27 May 2016; accepted 22 August 2016)

\begin{abstract}
An increase of innovative activity of small enterprises is included in the list of main directions of The Strategy of small and medium business development of Russian Federation for the period up to 2030. In the relevant sector of the economy the effectiveness of innovation is determined by the degree of its harmony. The work reflects the conceptual provisions of the harmonization of innovation processes in the internal and external environment in which small enterprises operate: the goal, objectives, object, principles and methods of harmonization are formulated as well. The harmonious relationships of innovation activity of small business are described by the dynamic model, in which indicators are ranked and subordinated to each other. The results of the practical approbation of the proposed methodology by types of economic activities are shown in the article.
\end{abstract}

Keywords: Innovation, harmonization, small enterprise, method of the dynamic standard

\section{INTRODUCTION}

According to the estimates of the Russian Federation Ministry of Economic Development (2016), now small and medium business (SMB) in Russia, generating more than $19 \%$ of GDP and occupying the $6 \%$ share of exports, however, is not the driver of the national economy yet. In 2014, the country's SMB sector, which is represented mainly by the microenterprises (small and medium-sized enterprises occupied over $95 \%$ of the total number of all operating in the country enterprises) showed fairly low level of business economic activity, in particular, on productivity, in the

\footnotetext{
* Corresponding author: irasomina@yandex.ru

DOI:10.5937/sjm11-11030
} 
value of turnover and its share in the total turnover of Russian companies, in the level of investment and innovation activity of Russian small enterprises of 2-3 times lagged from similar economic entities of developed countries. Within the current economic climate, at the federal level it was decided that the Strategy of small and medium business development of Russian Federation for the period up to 2030 is needed. The development of small and medium business as a factor of innovation and social development, improvement of branch structure of the economy and ensuring a consistently high level of employment should be the main goals of the Strategy. The first version of the draft strategy was considered by the Government Commission on the issues of competition and the development of small and medium-sized enterprises, in December 2015. According to the official website of the Russian Ministry of Economic Development of 02/04/2016, the revised draft containing specific measures to support small and medium-sized companies in the next two years was submitted to the Government. An improving of the functioning elements of the national, regional and territorial innovation systems, as well as improving of interaction between them in order to ensure favorable conditions for the formation and development of domestic high-tech companies are listed among the measures.

We assume, that the concept of harmonization which includes the appropriate methodological tools can become theoretical and methodological basis for solving problems mentioned above. Noting the increasing attention of scientists and economists, such as Kleiner (2008), Ivanus (2011), Muratov (2012) and others to the problems of searching of harmony in the area of economic development and innovation and recognizing their significant contribution to the forming of the modern theory of harmonious management, nevertheless, we consider that the results obtained by them can't solve all issues of this domain due to focusing of research on the solving these respective objectives. Thus, the lack of complexity in solving of objectives of harmonization of small business innovation activity by the scientists as well as the undoubted importance of the problem are the basis for the continuation of research in this direction.

\section{THEORETICAL BASIS OF THE HARMONIZATION}

World theory and practice of harmonization has a rich traditions and deep historical roots. It is known that the basic ideas of harmony were laid down in the works of Aristotle, Pythagoras, Euclid, Plato, Hegel, Fibonacci, Leonardo da Vinci and other great thinkers of humanity. The idea of harmony (as of agreed combination of heterogeneous elements) is widely used in different spheres of scientific and industrial activity and implemented in the economic and social space, social and political relations and in the art up to the present time.

The publication of F. Bastiat's work called "Economic Harmony" in 1880 is considered to be a "starting point" of the research of harmonization in the economy. According to Bastiat, the market economy is a kingdom of harmony and freedom because all economic agents "have to provide each other with mutual services and assistance to achieve a common goal" (Bastiat, 2014). Later scientific principles of the "artificial harmony" based on the active participation 
of the state in economic processes were developed by Marxists. Representatives of the American school of harmonious management have created a theoretical and methodological basis of the feasibility of the combination of natural and artificial elements of harmonies. The approach of national identification of economic harmonies of List (1909), Schumpeter (1994) and Reinert (2007) which was based on the substantiated proof of the national interests priority in international economic relations is the important step in development of theory of economic harmonies.

In recent decades the high practical significance was acquired by the structural approach to the harmonization of economic phenomena and processes which is based on using of the Fibonacci ratio or the principle of the "golden section" (0.618: 0.382). The wave theory which was created by Ralph Nelson Elliott is the most widely spread in this approach (Frost \& Prechter, 2012).

Besides, the development of balanced scorecard Kaplan-Norton, the organization balanced production Klevina-Moses, the concept of process approach, etc. should be recognized as scientific and reasonable reflections of the ideas of harmonization of economic parameters (indexes) of functioning entities.

\section{MAIN PART}

3.1. The general methodology for harmonization of innovation process in the sector of small business as an element of the national innovation system

Research of basic theories of economic harmony and harmonization of existing approaches to economic process makes it possible to conclude that these theories don't fully meet the innovative nature of the activity and specificity of small businesses (SB). For this reason, the author's methodology of innovative processes in the SB sector is proposed, it is based on the idea of harmony as some idealized static status of a system, elements of which are arranged and harmonized as much as possible and consistent to the environment. In turn, the harmonization is considered as a dynamic category, reflecting the process of striving to a harmonious state by identifying and removing internal imbalances, coordination conflicts between small businesses and the environment, and manifesting itself in improving of the effectiveness, quality and efficiency of innovative activity of the above subjects.

As a scientific and theoretical basis of the concept of harmonization of innovative processes in the SB sector, which is considered as an element of the national innovation system, we accept a systematic approach, innovation theory, process approach, synergistic paradigm, the theory of dynamics.

In the author's opinion the goal of harmonization of the innovation processes implemented by small businesses is increasing of the contribution of small enterprises to results of innovation activities of territorial entities and national economy, and transforming of the small business sector into the driver of Russian economic development in general.

The objects of harmonization are small businesses which act as elements of territorial and national innovation systems.

The methodological basis of harmonization of innovative activity of small enterprises (including the interaction 
between them and the other elements of the innovation system) is consisted of principles that reflect the nature of the harmonization and the characteristics of innovation processes, the specifics of small business namely comprehensiveness, consistency, proportionality, hierarchy, objectivity, flexibility, cycling, focus, synergies, strategic orientation and others.

The objectives of harmonization of the small business sector as an innovative element of the system are analysis of the dynamics and prospects of development of innovative activity of small businesses; assessment of the harmony of the parameters of innovation processes in the small business sector and its relationships with the external environment; development and implementation of measures for identification of disparities and harmonize contradictions.

This article is focused on the studying of the key parameters of the innovative activity of Russian small enterprises and methodological support of the level assessment of harmony.

\subsection{Assessment of the basic parameters} of the innovative activity in the Russian small business sector

Basing on the official data of the Federal State Statistics Service (2016), we analyze the key parameters of innovation activity of Russian small business subjects.

We can note that a statistical review of indicators of innovative activity of Russian small enterprises is carried out in the form №2-SB "Information on the technological innovation of small businesses" since 1999, its frequency can be every two years and the range of indicators is quite narrow. So, we have the official statistics to 2013 inclusively. Let us estimate the main outcomes with help of statistical material which we have.

In 2013, 1274 subjects of a small Russian business are engaged in the innovation and technological activities and it is twice as much than the level of figure in 2000 . However, the number of innovation-active small enterprises compared to the previous reporting period has fallen, that is a consequence of the crisis in the national economy and, therefore, a reflection of the business environment.

In general, during the years 2009-2013 the share of small enterprises which have implemented technological innovation in Russia, is relatively low and varies in the range of $4.1-5.1 \%$, it is almost twice as less than the indicator of large and medium Russian businesses (9.3-9.9\%) and in 10 times less than the level of innovation activity of enterprises in developed countries.In this class of small-sized enterprises there is a direct correlation dependence between the level of innovation activity of Russian small businesses and the number of their employees (Figure 1).

In 2013 "innovation leaders" among the Russian regions were the Altai region (13\%), Kursk (12.1\%) and Voronezh (9.7\%) regions. Manufacture of electrical and optical equipment (12.6\%) and chemical industry $(10.7 \%)$ traditionally are dominated.

By studying the dynamics of the costs of technological innovation in small businesses during the period under review, we note a double increase of the absolute value of index in current prices in the reporting year relatively to the level of 2009 (Figure 2).

We assume that this uptrend is rather a consequence of the recognized by world analysts phenomenon of "increasing in costs" of innovation than its scaling in 


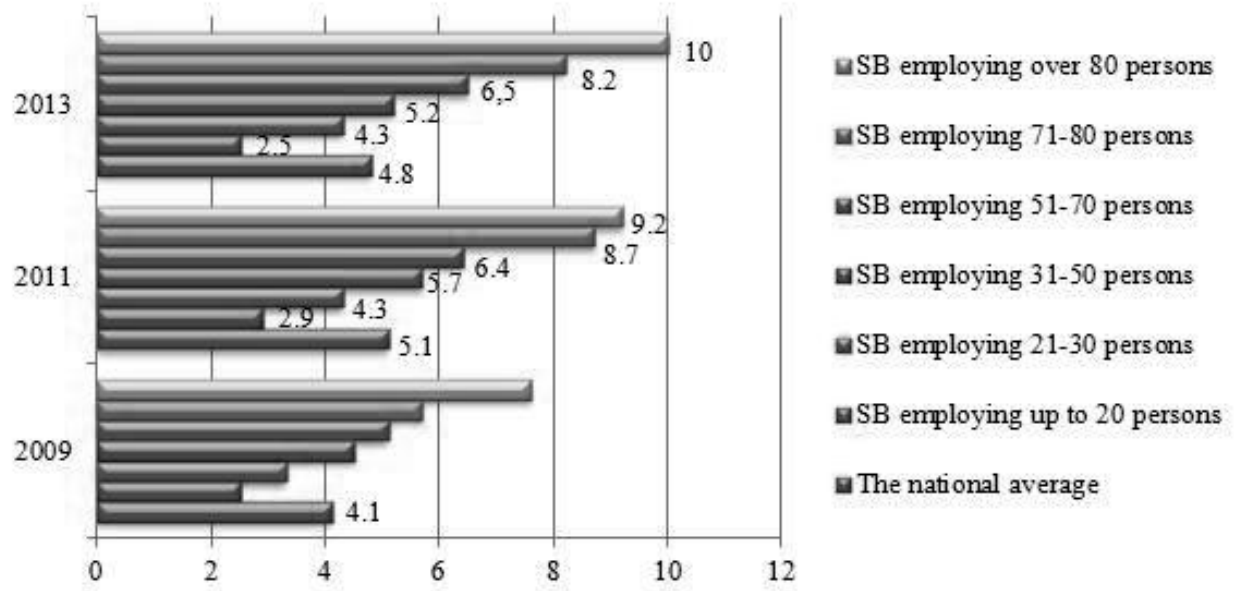

Figure 1. The share of small business in Russia, implemented technological innovations (is based on data compiled by the Federal State Statistics Service (2016))

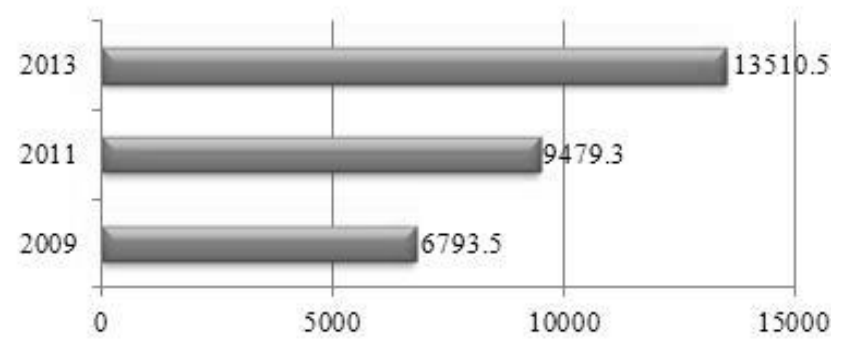

Figure 2. Dynamics of the costs of technological innovation of Russian Federation small enterprises, RUR $\operatorname{mln}$.

Russian small business sector.

At the same time the RF Government's measures which stimulate innovation activities of small businesses should be noted. Thus, on the state level with the participation of institutions of the development a system of grant and loan investments in innovative projects on various stages of the innovation cycle ("innovation elevator") was created; Russian current tax legislation has granted benefits on compulsory insurance contributions to small and medium enterprises; a favorable tax regime for venture capital investment and implementation of innovative entrepreneurship was established.

In the cost structure of technological innovation of Russian small enterprises the expenses related to purchasing of machinery and equipment are amounted more than 30 $\%$. In the context of economic activity in 2013 the most attractive investments were in the area of manufacture of electrical and optical equipment (it took $34.3 \%$ of the total value of expenses on technological innovation of small businesses), machinery equipment (14.1\%) and food products $(12.2 \%)$.

We suppose that certain restrictions of small business innovation can be overcome by the using of different cross-financing schemes of their activities assuming the interaction with public authorities, financial institutions, the academic sector, large businesses and private investors. In particular, the proposal for using these sources of financing of innovation in small businesses as mezzanine financing, 


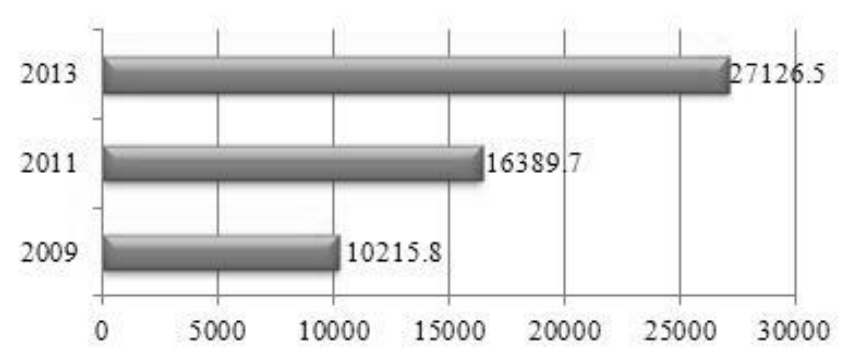

Figure 3. Dynamics of innovative products, works and services of small enterprises in the Russian Federation, RUR mln.

crowdfunding and syndicated financing was substantiated in our earlier works (Doroshenko et al., 2013; Doroshenko et al., 2015).

Assessing the indicators of innovative activity of small enterprises in Russia, it should be noted, that there is a the steady growth of innovative products in absolute terms on one hand and maintaining of a sufficiently low level of the ratio of innovative products, services and the total value of shipped by small businesses goods, works and services (in $2013-2.07 \%$ ) on the other hand.

Looking at this index in the context of the major types of economic activities the production of a chemical $(3.68 \%)$, and manufacturing of electronics, electrical and optical equipment $(8.79 \%)$ should be allocated. The effectiveness of innovation activity in other areas is less than the national average. Summarizing our analytical research results of innovative activity in the Russian sector of small business, despite some positive trends, we should make a conclusion about the low importance of innovative processes in the economic development of the sector.

Indeed, statistics on innovative activity of small business enterprises needs to be supplemented and developed. It will promote more efficient and accurate recognition of tendencies and issues in this field, as well as identification of its reasons. Also, this actions will contribute to the development of measures on adjustment of negatively oriented trends. But even a limited quantity of statistical data at our disposal enables to conclude that innovative activity of small business enterprises are highly differentiated in such parameters as a number of employees, location and type of economic activity.

\subsection{The harmony degree appraisal of} key parameters of innovative processes implemented by small business enterprises in the Russian Federation by types of economic activities

It is being proposed that the processoriented approach and the method of dynamic standard will be used as methodological tools for research on comparability and hierarchy of innovative activity's parameters in the dynamics. The basics of these approaches are outlined by Syroyezhkin (1980).

The classical understanding of the process essence states that it is an activity, during which "inputs" transform into "outputs" through the use of appropriate resources. Taking into account the meaning with relevant to this representation correlations between growth rates of "input", resource availability and "output" and our recent 
studies (Somina, 2014; Tumin \& Somina, 2014), we will obtain the next standard range concerning innovative activity's statistic parameters of small business enterprises:

$R_{g_{\text {quan }}}>R_{g_{\text {cos }}}>R_{g_{\text {goods }}}$,

where $R_{g_{\text {num }}}$ is a growth rate of a quantity of an innovatively active small business enterprises; $R_{g_{c o s}}$ is a growth rate of costs on technology innovations in small business enterprises; $R_{g_{\text {prod }}}$ is a growth rate of volumes of innovative goods, works, services in small business enterprises.

It has become an obvious fact for us that hand-to-mouth enumeration ofinnovative activity's parameters of small business enterprises shown in official statistical sources unjustifiably limits possibilities of using a proposed estimated tools. Particularly, official statistical data of small business enterprises does not contain information about such parameters of innovative process's stages as research and development, technology transfer. At the same time, according to Rosstat database in 2014 year there are 15220 small business enterprises just in the sphere of research and development for which the aspects referred stand out as major.

An aspirationto enhance the effectiveness of investment and financial support to innovative processes and to ensure a profitability of innovative activity in small business enterprises formed the basis of an economic interpretation of correlation constructed by us (1).

Desired standard range can be transformed through the standard mathematical algorithm into the matrix form like this: $p_{i j}=\left\{\begin{array}{c}1 \text { at } T_{i}>T_{j} \text { or } i=j \\ -1 \text { at } T_{i}<T_{j}\end{array}\right.$,

where $\mathrm{p}_{i j}$ is a constituent of ordering matrix; $\mathrm{i}$ - a matrix row number, $\mathrm{j}$ - a matrix column number; $T_{i}$ and $T_{j}$ are growth rates of $\mathrm{i}$ and $\mathrm{j}$.

In the given correlations of growth rates innovative processes in the small business sector matrix assumes the following form (3):

$$
\left(\begin{array}{ccc}
1 & -1 & -1 \\
1 & 1 & -1 \\
1 & 1 & 1
\end{array}\right)
$$

The matrix of actual correlations between growth rates of discussed innovative process's parameters is formed likewise $\left\{f_{i j}\right\}$.

Further, corresponding element of the actual correlations matrix $f_{i j}$ is deducted from every element of the standard ordering matrix $\mathrm{p}_{i j}$. Thus, we obtain the difference matrix $\left\{r_{i j}\right\}$. Its elements are determined by the formula (4):

$r_{i j}=\left|p_{i j}-f_{i j}\right|$

The extent of deviation of the actual correlation of growth rates from the standard can be estimated by calculation of normalized interval between the standard ordering matrix and the difference matrix:

$S=1-\sum_{i=1}^{n} \sum_{j=1}^{n} r_{i j} / 2 N$

where $\mathrm{N}$ is a number of elements of the initial matrix except for elements on the diagonal $i=j$. 
The range of $\mathrm{S}$ is in the interval of $[0 ; 1]$. The economic interpretation of this range can be formulated as follows: as the $\mathrm{S}$ gets closer to the 1, actual correlation of growth rates of innovative process's paremeters in the sector of small business enterprises are increasingly corresponding to the standard (harmonious) state.

The standard correlation constructed by us is based on three parameters obtained as a result of calculation of normalized interval between the standard ordering matrix and the difference matrix. Therefore, small business enterprises of corresponding type of economic activity can be divided into four categories according to the harmony degree of innovative processes's parameters:

1) A zero level of harmony degree of innovative processes's key parameters $(S=0)$ shows that the actual dynamics of innovative activity's parameters is unbalanced and does not correspond to its standard correlation.

2) A low level of harmony degree of innovative processes's key parameters $(S=0,333)$ is an index of presence of explicit distortions between a quantity of small business enterprises involved in innovative activity, its resource availability and efficiency of this activity.

3) An average level of harmony degree of innovative processes's key parameters $(S=0,667)$ shows that innovative processes undertaken in small business enterprises are disproportionately scaled or show the decrease of the efficiency.

4) A high level of harmony degree of innovative processes's key parameters $(S=1)$ is an index of proportional harmonious

Table 1. Growth rates of innovative activity's parameters of small business enterprises in the Russian Federation by types of economic activities over the period from 2011 to 2013

\begin{tabular}{|c|c|c|c|}
\hline Type of economic activity & $\begin{array}{l}\text { A growth rate of a } \\
\text { quantity of innovatively } \\
\text { active small sized } \\
\text { enterprises }\end{array}$ & $\begin{array}{l}\text { A growth rate of costs on } \\
\text { technology innovations in } \\
\text { small sized enterprises }\end{array}$ & $\begin{array}{l}\text { A growth rate of volumes of } \\
\text { innovative goods, works, } \\
\text { services in small sized } \\
\text { enterprises }\end{array}$ \\
\hline The mining (resource extraction) & 1.07 & 1.19 & 1.33 \\
\hline The food-processing industry & 1.03 & 1.10 & 1.63 \\
\hline The sewing and textile industry & 1.04 & 2.50 & 1.33 \\
\hline The wood processing industry & 0.84 & 0.88 & 0.33 \\
\hline The pulp-and-paper industry & 0.75 & 0.87 & 1.42 \\
\hline Thechemical industry & 0.96 & 0.85 & 1.94 \\
\hline $\begin{array}{l}\text { The production of rubber and } \\
\text { plastic products }\end{array}$ & 0.88 & 1.21 & 1.19 \\
\hline $\begin{array}{l}\text { The production of other non metal } \\
\text { mineral products }\end{array}$ & 1.06 & 0.85 & 1.42 \\
\hline $\begin{array}{l}\text { The metallurgical industry and the } \\
\text { finished metal goods production }\end{array}$ & 1.35 & 1.61 & 2.41 \\
\hline $\begin{array}{l}\text { The production of machinery and } \\
\text { equipment }\end{array}$ & 1.43 & 2.09 & 1.89 \\
\hline $\begin{array}{l}\text { The production of electrical } \\
\text { equipment, electronics and } \\
\text { optical equipment }\end{array}$ & 1.06 & 2.44 & 1.81 \\
\hline $\begin{array}{l}\text { The Production of vehicles and } \\
\text { equipment }\end{array}$ & 0.89 & 0.94 & 2.12 \\
\hline $\begin{array}{l}\text { The production and distribution of } \\
\text { electrical power, gas, and water }\end{array}$ & 0.80 & 0.55 & 0.76 \\
\hline
\end{tabular}


development of innovative processes's key parameters in the sector of small business.

The results from the practical approval of the proposed method by the example of small business enterprises by types of economic activities are presented in the table below. Being based on the data compiled by Federal State Statistics Service (2016) we will form the initial database of innovative activity's parameters over the period from 2011 to 2013 and calculate growth rates (table 1).

The obtained results of calculation of normalized interval based on construction of the actual matrix and the difference matrix are presented at figure 4 .

Thus, it should be recognized that during the research period the maximum harmonious changes of innovative activity's parameters were observed in small business enterprises of the following types of economic activities: production of vehicles and equipment; metallurgical industry and the finished metal goods production; pulpand-paper industry; food-processing industry and mining. On the other hand, a low harmony level of innovative processes's key parameters requiring a thorough analysis and a determination of the causes were observed amongsmall business enterprises engaged inwood processing, production and distribution of electrical power, gas, and water. In other industries of small business's presence, discrepancies with the standard correlation of growth rates of innovative activity's parameters are insignificant, but it should not be neglected.

\section{DISCUSSION OF RESULTS}

In summary, it is possible to draw the following conclusions:

1. Under the economic circumstances

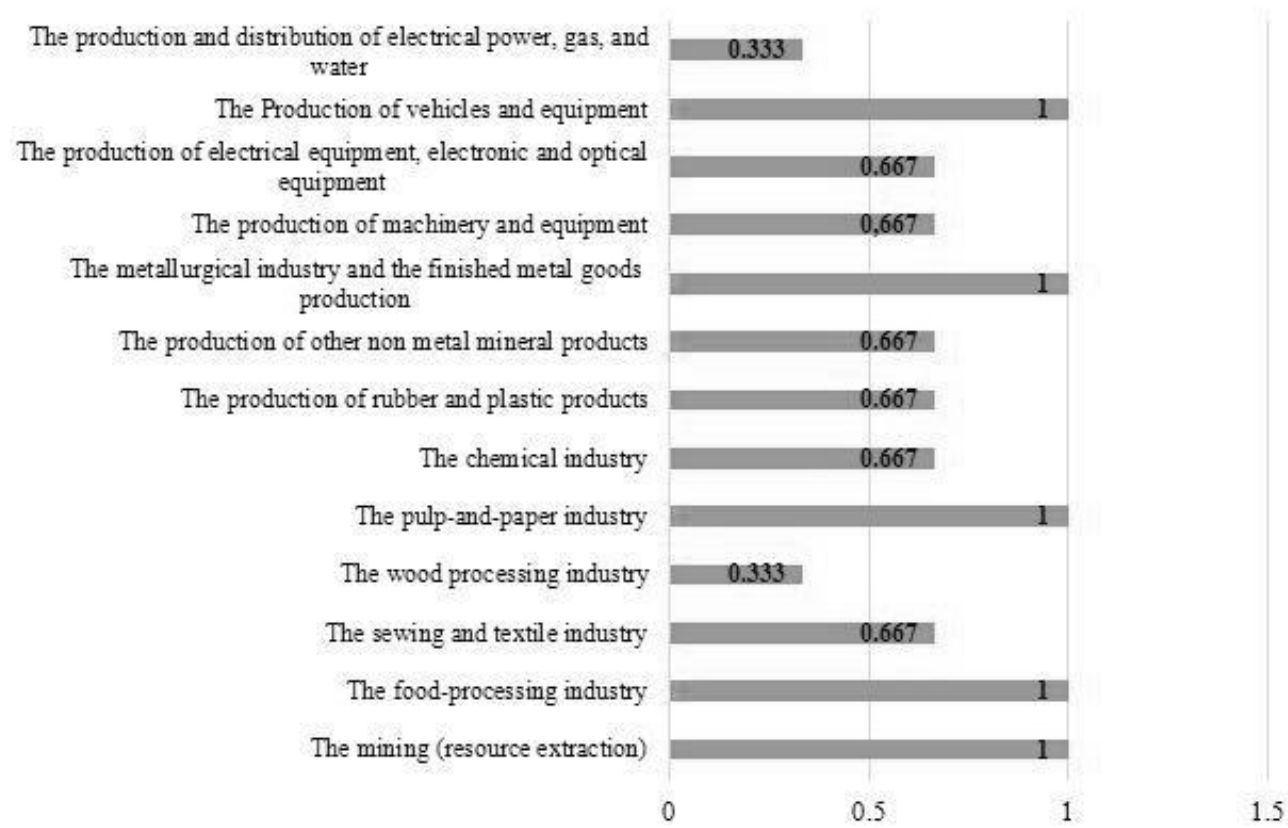

Figure 4. The dimension of normalized interval between the standard matrix and the actual matrix, which shows a harmony degree of innovative processes's parameters in the sector of small business enterprises (by types of economic activities) 
prevailing in Russia, expediency of the harmonization of innovative activity of small business enterprises is clear. The propositions of fundamental theories of economic harmonies as well as authors' suggestions on the development of the current methodology relative to the subject of the present research can serve as a methodological foundations of the harmonization process.

2. The research of innovative activity of small business enterprises in Russia concluded that innovative processes are of little importance for economic development of small business sector; innovative activity of small business enterprises was identified as highly differentiated in such parameters as a number of employees, location and types of economic activity. In addition, the necessity of supplement and development of statistics of innovative activity in small business enterprises were proved.

3. The mathematical framework of the dynamic norm method was assumed as methodological basis for the harmony degree appraisal of key parameters of innovative processes implemented by small business enterprises in Russia. The proposed methodology is based on calculation of normalized interval between the standard ordering matrix and the difference matrix which conform to the standard range and the actual range of appropriate growth rates.

4. The results from the practical approval of the proposed methodology based on the statistics of innovative activity of small business enterprises in Russian Federation are presented in the research. Types of economic activity in the small business sector were compared in the proximity of growth rates of innovative processes' key parameters to the standard (harmonious) range.

\section{CONCLUSION}

The following issues observed over the recent years have become the most important prerequisites for research:

- the increased interest of representatives of economic science in harmonization issues;

- the scale effects of imbalance and contradictory tendencies in socio-economic field;

- an insignificant contribution of small business enterprises in Russia to indicators of innovative and economic development of country;

- strategic objectives of small and medium businesses development in Russia.

Author's methodology of innovative processes' harmonization in small business sector assumes the concept specification of harmony and harmonization relative to the subject and the object of this article and involves formulating the goals, the objectives, the guidelines and the methodic basis of harmonization process.

The presented methodological tools give the numerical assessment to harmony level of key parameters of innovative processes undertaken in small business enterprises, what also allows to conduct interregional and interspecific comparisons.

Factor analysis based on estimation of changes of innovative processes' parameters and environment, in which small business enterprises operate can be the possible direction of the development of the method under discussion. Thus revealed weaknesses of the process and its ranking according to the extent of their influence on the development of national innovative systems allowed to determine a range of high priority issues whose solution would produce significant result. 
In conclusion, it should be mentioned that achieving growth in all indicators for the innovative processes during each time interval is impossible in practice. However, even during economic crisises in case of negative tendencies in changes of absolute values, one must endeavor to ensure standard correlation growth rates. The above statements attached additional practical value to the proposed approach.

\section{Acknowledgement}

The article was published with the financial support from Ministry of Education and Science of the Russian Federation within the framework of state assignment to the project \#26.1511.2014K "Theory and methodology of managing innovational and investment processes in small business enterprises."

\title{
МЕТОДОЛОШКИ И ПРАКТИЧНИ АСПЕКТИ ХАРМОНИЗАЦИЈЕ ИНОВАТИВНИХ ПРОЦЕСА У СЕКТОРУ МАЛИХ И СРЕДЫИХ ПРЕДУЗЕһА РУСИЈЕ
}

\author{
Yuri Anatolievich Doroshenko, Irina Vladimirovna Somina
}

\begin{abstract}
Извод
Пораст иновативних активности малих предузећа укључен је у списак главних праваца Стратегије развоја малог и средњег пословања Руске Федереције, за период до 2030. У релевантном сектору економије, ефективност иновације је одређена нивоом хармонизације са окружењем. Овај рад представља концептуалну процену хармонизације иновативних процеса у интерном и екстерном окружењу, у којем мала предузећа послују: циљеви, принципи, правци и методе хармонизације су такође описани.Хармонијске релације иновативних активности малих предузећа су описане динамичким моделом, у којем су индикатори рангирани и хијерархијски међусобно повезани. У раду су представљени резултати практичне примене предложене методологије, према типовима економских активности пословања.
\end{abstract}

Кључне речи: Иновација, хармонизација, мала предузећа, метод динамичких стандарда

\section{References}

Bastiat, M.F. (2014) Sophismes Economiques. Createspace.

Doroshenko, Y.A., Somina, I.V., \& Komissarov, S.A. (2013). Sources of Financing and Innovative and Investment Activity of Small Enterprises. World Applied Sciences Journal, 25 (6), 975-982.

Doroshenko, Y.A., Somina, I.V., Komissarov, S.A., \& Doroshenko, S.Y.
(2015). The Essence and Characteristics of Investment Processes in Small Innovative Enterprises. Asian Social Science, 11 (6), 185-191.

Frost, A., \& Prechter, R. (2012). Elliott wave principle - Key to understanding of the market. Moscow: Alpina Pablisher.

Ivanus, A.I. (2011). Harmonious innovation management. Moscow: Book house of "LIBROKOM".

Kleyner, G.B. (2008). The economy has 
to be harmonious. Economy and life, 19.

URL: http://kleiner.ru/arpab/ekon.html (in Russian)

List, F. (1909). The National System of Political Economy by Friedrich List. Sampson S. Lloyd, with an Introduction by J. Shield Nicholson. London: Longmans, Green and Co.

Muratov, A.S. (2012). The Harmony approach to economic systems management. Management of economic systems, 41 (5). URL: http://uecs .ru/uecs41412012/item/1342-2012-05-14-06-38-05 (in Russian)

Official site of the Ministry of Economic Development of the Russian Federation. URL: http://economy .gov.ru/minec/about/structure/depmb/20160 40203

Official site of Federal State Statistics Service. URL: http://www.gks.ru

Reinert, S.E. (2007). How Rich Countries Got Rich... and Why Poor Countries Stay. Poor, London: Constable and Robinson Ltd.

Schumpeter, J.A. (1994). Capitalism, socialism, and democracy. London: Routledge.

Somina, I.V. (2014). Using of the dynamic standard method in assessment of innovative processes in economy. The bulletin of the Belgorod state technological university of V.G. Shukhov, 1, 116-120.

Syroyezhkin, I.M. (1980). Improvement of indicators system of efficiency and quality. Moscow: Economy. (in Russian)

Tumin, V.M., \& Somina, I.V. (2014). A comparative assessment of innovative development level of the Russian regions by using of dynamic model (on the example of regions of the Central federal district). The bulletin of the Belgorod state technological university of V.G. Shukhov, 6, 168-171. 